\title{
Clinical and Immunological Results Obtained with the Marianum Antigen after more than Ten Years of Therapeutic Use
}

\author{
DR. P. ONDOUA,
}

Chief Medical Officer of the Hygiene and Preventive Medicine Service for Dja Lobo, and Nden, Cameroun

MISS M. TH. PROST,

Directress of St. Michel I eprosarium, Nden, Cameroun

SISTER M. DE LA TRINITE,

Directress of the Leprosy Research I aboratory, I.yons, France

In 1952 the experimental study of the Marianum antigen was begun at the St. Michel Leprosarium, Nden by DR. M. BLANC. His first report was on 457 patients in I 954. The results being satisfactory the antigen was applied in therapy for all new patients of the leprosarium. Since that time we estimate that about $\mathrm{I}, 500$ patients have derived benefit from this therapy.

The present paper comprises a detailed report on the results obtained with combined treatment with sulphone and Marianum antigen over ten years.

The Mitsuda test is carried out on every paticnt before the treatment is begun, and the test repeated every year. Every six months bacteriological examinations are made. Using the customary technique, the patients every month receive intradermal injections of $\mathrm{o}$. $\mathrm{o} \mathrm{ml}$. of the Marianum antigen. This goes on for six months and is followed by a rest period of three months and then another course of injections is begun. The therapy is really a combined one with sulphone or other anti-leprosy drug, such as Ciba I 9o6, or Sultirene.

In this report, certain phrases are used which have the meanings given, namely:

'arrested' - no clinical nor bacteriological activity for one year;

'much improved' - the clinical improvement is great, and the bacteriological examinations are negative for one year;

'improved' - there is clinical improvement and bacteriological findings are still undecided;

'stationary';

'worse';

The reactions to the Mitsuda are described in the usual way, negative (-), slightly positive $(+)$, positive $(++)$, highly positive $(+++)$.

I. Results with 260 leprosarium inpatients. These consisted of 57 lepromatous patients, 64 tuberculoid, and 145 indeterminate, and their classification 
of leprosy was scen and adjusted by DR. MARTinez of W'HO in March, i 961 .

The clinical results were immediately interesting, for there were i 3 'arrested', 65 much improved, 52 improved, $3^{1}$ stationary, and five worse. From the point of view of the type of leprosy, the results were even more interesting, for 72.0 per cent lepromatous patients benefited from the treatment, 89.2 per cent tuberculoid, and 90.9 per cent indeterminate. To achieve this result, the number of injections given varied from I 2 to 45 , and a better result is obtained from the larger number of injections (between 30 and 40 injections).

'The regular giving of the Mitsuda test at the beginning of treatment and once a year enabled the study of the action of the Marianum antigen according to the type of the discase. In all the rate of conversion to definite positive was high, mostly 90 to 100 per cent, though there were a few patients with a lower conversion rate of 66 to 83 per cent. 'Those who were positive kefore treatment ( 83 patients) remained positive in 97.5 per cent. 'There was an upgrading of degree of positivity in the slightly positive. If positivization of the Mitsuda comes it was noted that it comes more certainly at the end of the second course of the Marianum antigen, which consists of 12 more injections or more.

2. Results with 53 previous patients of the Sangmelia leprosarium who had previously the Marianum antigen: these patients were four lepromatous, Io tuberculoid, and 39 indeterminate.

The results were that 34 per cent were 'arrested', 35.9 per cent much improved, and 30 . I per cent improved. 'The Mitsuda changes to positivation were 67 to 77 per cent to definite positive $(++)$, and 28 negatives to positve $(++)$ were noted. These results had been obtained on six to I 2 injections in 47 patients, and 12 to 24 injections in six patients. A greater percentage of positive Mitsuda tests might have been obtained with more courses of Marianum injections.

3. Results with 30 previous contacts of the patients of $\mathcal{N}$ den leprosarium. Of these contacts there were i I children and I 9 adults, of whom six children born at the leprosarium had received BCG vaccination. In the group there were eight tuberculoid and 22 indeterminate patients, and of the six children vaccinated with BCG, four had no clinical nor bacteriological activity, one had no clinical activity but variable bacteriology, and one still had suspicious patches. The general results were for these 3 I patients that 23.3 per cent were 'arrested', 36.6 per cent much improved, and 40 per cent improved. The changes in the Mitsuda were that all six who were positive $(++)$ before, remained positive $(++)$. Of seven who were mildly positive before $(+)$, six became definitely positive $(++)$, and of I 7 who were negative, I 3 became definitely positive $(++)$.

4. Considering results with 124 patients who received this treatment but left the leprosarium a short time ago, studying their condition at departure and assuming that their lack of return significs that their leprosy condition has 
not changed, we report that of 18 lepromatous patients, 29 tuberculoid, and 77 indeterminate, the clinical changes were 29 per cent much improved, 27.4 per cent improved, 40.3 per cent stationary, and 3.2 per cent worse. About half of these patients had been treated for one to six years. The Mitsuda changes were favourable in 78 to 1 oo per cent in the various groups of the three main types.

5. An extra study of the Mitsuda reaction was made in $4 \mathrm{I} 2$ patients who had received benefit from the Marianum therapy, but who left the leprosarium at an early date. 'This group included 75 lepromatous patients, 94 tuberculoid, and 243 indeterminate. Of 227 who were negative to the Mitsuda before, 33 were negative at the end (or 14.5 per cent). Of the same number, I 94 became positive $(++)$, or 85.4 per cent. Of 185 who were positive before 14 or 7.5 per cent became negative, and 17 I remained positive $(++)$, or $9^{2} .4$ per cent.

6. Results from BCG vaccination of contacts living at the leprosarium. 'There were 92 children living in permanent contact with their parents and other inpatients of the leprosarium. 'These were all examined, as all of them had one or more courses of Marianum antigen since i 960 . On the suggestion of DR. GAY PRIETO, they also had been given prophylactic sulphone. Study was made of 73 children and the others discarded, as they were only a few months old, and had had too short a prophylactic treatment, although none showed any sign of leprosy.

Most of the children in the group studied had been born at the leprosarium, or admitted with their parents at the age of six to eight months. Of the children only i 3 were aged 7, 8, io, or I 2 years at the time of their admission and at the beginning of BCG vaccination. Although they had a few years contact with their parents, they showed no difference from the others in respect to changes in the Mitsuda reaction.

After 6 to 30 injections of Marianum this group also showed considerable favourable modification of the Mitsuda.

Of the children, 88 show no sign of leprosy, and four only a suspicious patch with no sign of activity.

In comparison, data from Bafia leprosarium was studied concerning child contacts, and it was found that over five years the percentage of infection was 4.75 per cent.

The children were given BCG a few weeks after birth, as well as prophylactic sulphone (Disulone). As is seen in Section 3 of this paper, six children vaccinated with BCG out of 30 contacts developed leprosy. In fact out of 225 child contacts observed over two years to whom BCG vaccination was given, the percentage of infection was 2.6 per cent.

This paper reports on the records of 885 patients treated with the Marianum antigen; of 349 inpatients of the leprosarium, 86.5 per cent received 
benefit from this therapy as 'arrested' or improved, I 2 . I per cent remained stationary, and I 4 per cent worse.

Concomitant study of the Mitsuda reaction showed that in 349 inpatients a previously negative Mitsuda became positive in $8 \mathrm{I}$. 7 per cent (there were originally 59 negative Mitsudas) and remains positive to date, and Io per cent attained a positive but unstable Mitsuda. Most of the conversion of the Mitsuda was noted after 12 injections of Marianum antigen, and remained constant.

Of the 536 patients studied, there were 357 with a negative Mitsuda. These became positive in a percentage of 85.9 per cent.

In contrast with the gencral opinion of leprologists that the first few years of sulphone therapy results only in a low percentage of positive Mitsudas, the present study has shown that even in $I_{2}^{1}$ to 2 years, a high percentage is obtained. This means at the end of the second course of injections of Marianum antigen.

'The authors think that this antigen is a good adjuvant in therapy, which reinforces the resistance of the patient, and permits a better and safer response to chemotherapy. 'The absence of relapse over the two year period is most striking, and is attested by MISS M. TH. PROST, Directress of St. Michel Ieprosarium.

From the point of view of prophylaxis, the authors draw attention to the low percentage of infection among permanent contacts, and cite the 92 children, who might have been considered to have a high susceptibility to infectious diseases.

\section{References}

I 953-M. Blanc and M. Th. Prost - Present therapy of leprosy at St-Michel Leprosarium, Nden (Cameroun).

St. Med. and anat. Clin. de Lille - séance du 26/1 I/52.

Journée des Sciences Médicales de Lille, No. 3- 7 I è An. I5/3/53, p. I 29 à 139 .

1953-M. Blanc and M. Th. Prost - Our projects and our realisations regarding the prophylaxis of leprosy. St. Med and Anat. Clin. de Lille - Séance du 26/1 i/52.

Journal des Sciences Méd. de Lille - No. 3 - 7 I è An. I5/5/53, p. I 39 à I 42 .

1953-M. Blanc and M. Th. Prost - New orientation with regard to the prophylaxis of Leprosy in Cameroun - Congrès International de la Lèpre, Madrid (1953).

I953-M. Blanc, M. Th. Prost and Sr. M. Suzanne - The influence of a Mycobacterium isolated from leprosy tissue, strain Chauviré, on the Mitsuda reaction.

Bull. Soc. Path. Exot. 8/7/53, No. 6, p. 1009 à 1014 .

1953-M. Blanc, M. Th. Prost, Lemaire, E. Kuna et 7. M. Nkoa - Immunological study of the Antigen Chauviré.

Ann. Biol. Clin. No. ı-12, Oct. Déc. 54, P. I à 6.

Journal Soc. Méd. de Lille 1953 - No. i 2, pp. 384-39o.

I 954-M. Blanc. M. Th. Prost. Michel, Lemaire, Kuna E., Esselé J., and Nkoa 7. M. - Clinical and therapeutic study of an antigen prepared with the Mycobacterium marianum, and its application on 457 Leprosy patients.

Ann. Biol. No. 10-12- Oct. Déc. 1954, p. I à 12.

Intern. Journal of Leprosy - January-March 1955-Vol. 23, No. I, P. 23 à 31 .

I955- $M$. Blanc - Study of the reactions caused by the antigen Marianum.

Sté Méd. and Anatomo-clinique de Lille - Séance du I6 Mars I 955.

Journal des Sciences Méd. de Lille No. 5 - 73è Ann. Mai 1955. 
I955-M. Blanc, M. Th. Prost - Clincal research on the immunological and therapeutic properties of the antigen Marianum.

Rev. Colon. de Médecine and Chirurgie - No. 241, 27 è ann. 15/12/55, pp. 226-236.

I956-M. Blanc - New orientation of the anti-leprosy campaign in Cameroun. Congresso Internationale per la difesa e la riabilirazione sociale del 'Lebbroso' Roma, p. 418 à 426, Vol. II - I6-18, Aprile I 956.

1956-M. Blanc, M. Th. Prost - Leprosy survey in the Schools of the district of Dja and Lobo - Prophylaxy with the Anti-lépreux Vaccin sm. sm.

Congresso Internazionale per la difesa e la riabilitazione sociale del 'Lebbroso' Roma, ı6-ı 8 Aprile ı956, Atti e memorie V.II, p. I 38 à I 49. 